\title{
Design of Tortor Revitalization As A Learning Model for Batak Toba
}

\author{
Yusnizar Heniwaty ${ }^{1 *}$, Sitti Rahmah ${ }^{2}$, Iskandar Muda ${ }^{3}$ \\ Unversitas Negeri Medan, Indonesia \\ *yusnizarheni@unimed.ac.id
}

\begin{abstract}
The purpose of this study is to revitalize the Toba Batak tortor in traditional activities in the life of the Batak community, which makes tortor as a medium of expression of gratitude, respect, affection, which is carried out with structured movements as messengers. Tortor is a dance in Indonesian that reflects the lives of the Toba Batak people, who are slowly being abandoned by their owners for various reasons. This research is also motivated by the lack of accurate documentation in the form of writing, video, and other forms of documentation, so that in an effort to familiarize the art, inheritance is carried out through revitalization of tortor. Based on this, relating to the learning of ethnic dance custom torture revitalization activities are used as a model of learning media development. Tortor learning is done by developing Adobe Flass digital media as a tool for the process of transferring knowledge, through the revitalization of tortor as a learning model. This research is a developmental study using descriptive analysis method with a qualitative form, by means of observation, interviews, and documents. From the data that has been collected, data analysis is then carried out in stages; data reduction, data display, and conclusion drawing. To obtain valid data, the data validity test is done using a triangulation model, and the learning media validation through media validation and material validation.
\end{abstract}

Keyword: Tortor, Toba Batak, Revitalization,

\section{Introduction}

The progress of the times that is developing at this time causes the local traditions and culture of its existence to begin to change from its original form. They prefer the demands of the times by prioritizing demands rather than inherent culture. Truly the culture that already exists. is a culture that is very compatible with the nation's personality. Forms of outside culture become a spectacle of the young generation with all kinds of patterns, without thinking about the impact. Handling should be carried out in a hurry to restrain culture that is not in accordance with the norms in Indonesia, by introducing the culture of the region itself in the introduction of the introduction process.

Tortor is an art of the Toba Batak tribe that is currently being abandoned by its owner. Many factors cause this to happen such as; the next generation no longer cares about its culture, references to Batak art that are not well publicized. Many studios teach tortors and develop them in the form of Batak dance creations that are displayed in various activities. But the work produced is not always as expected, even sometimes damaging the order, the arrangement that applies in a group of people. This problem arises due to the lack of 
information to invite the testator to preserve art forms, both in performances and in learning and documentation that is absolutely supposed to be done.

So far, the inheritance of traditional arts has only been aimed at mastering motion material without being equipped with an understanding of the meaning in dance. Finally in the development process, many choreographers develop without thinking about how the forms already exist in the format they should. If this is left unchecked, it is not impossible that one day the structure of the original form of a traditional dance work will be lost, and the development will be limited to an order that will further eliminate its traditionalism.

One of the efforts to strengthen and preserve tortor is one of them through learning by making it as a learning resource, which in turn can strengthen understanding for tortor mastery. Judistira [1] explains that local culture is not only revealed from the form and expression of a sense of beauty through mere art; but includes all forms, and ways of behaving, acting, and mind patterns that are far behind what appears. Thus the effort to raise again with the aim of introducing tortor, will be conveyed properly, and learning objectives will be achieved according to competence.

As a high cultural value and cultural heritage, tortor certainly must be maintained and developed, by observing the Toba Batak tortor as a traditional dance that deserves to be inherited, so there is a need for new methods in transferring knowledge. Several stages must be carried out in an effort to preserve the cultural heritage, ranging from controlling, inventory and documentation, introduction, to its development.

Seeing the above problems, improvement is needed in providing an understanding of the basis mastered by dancers, so this research is important to be carried out in order to examine what strategic steps can be taken in preserving traditional art forms, so that through this research it is hoped that inheritance of the Toba Batak Tortor can done through revitalization.

Revitalization is a process or method and act to revive something that has previously been lost and to revive any program of activities. In general these activities are efforts to make something important and very necessary. Indonesia is a nation that is famous for its cultural diversity. Therefore, it is appropriate that all levels of society pay attention to playing an active role and participating in efforts to preserve the nation's culture. Culture is the result of human creativity, initiative, and work in the form of science and norms such as the norm of beauty that then produces various kinds of arts.

This study aims to reveal in depth about the forms of traditional ceremonies that include tortor as part of its implementation in general, and specifically aims to revitalize tortor in the traditional ceremonies of the Toba Batak people.

Ediwar [2] explains the art of rapa'i that began to be abandoned after the Tsunami, so that strategic steps are needed to maintain its continuity. For this reason, an understanding of this culture is needed, that rapa'i is a type of Islamic nuanced art that is loaded with religious, cultural, social, beauty and educational values. This art is used as a medium for da'wah and acculturation with local culture. The meaning of expressive symbols of art and religion gives rise to the robustness of the values of Islamic cultural and religious spirituality. Collaboration of music, dance and literature is a special feature that has made rapa'i art as a cultural identity of Aceh. Therefore, rapa'i art must be re-manifested in various activities to return this art to its owner.

Marsudi's [3] explained that the shift of traditional culture to digital culture, based on the abandonment of art and traditional culture by the student. It is in an effort to enhance students' appreciative attitudes towards local art works by developing learning media. One of them is the making of digital learning media through the use of poor mask craft for learning arts and culture at the junior high level. From the results of this study, it is known that the use of digital 
media with attractive display is very helpful for students in understanding and appreciating the culture of the local area. This study serves as a guideline for researchers to analyze regional art as a source in the preparation of digital media in Tortor learning.

Furthermore Awaludin Muin [4] explains that, the role of interactive multimedia increasingly plays a very important role in the field of education in line with the growth of the use of multimedia to facilitate the learning process. The ability is to design appropriate interactive multimedia, integrating with Microsoft Office PowerPoint 2007. Learning art and culture in elementary schools requires new media and methods so students are motivated to learn. Through interactive multimedia learning in elementary schools is expected to increase student motivation. The results of this study can help researchers in designing learning media.

The reference above becomes a reference for researchers, to see how the traditional arts are slowly abandoned by their owners, so that re-appointment of these arts is needed. By revitalizing, it is hoped that culture can be brought back to its owner, by making it a source of learning.

\section{Research Method}

This research uses descriptive qualitative method by describing the importance of revitalizing local culture in learning the Toba Batak Dance Technique. Sugiyono [5] states that in qualitative research, the research instrument is the researcher himself. In this study, researchers participated directly in the field so that after making observations, researchers can find clear problems and obtain detailed research reports. The study was conducted using several stages, from the collection of library study data, observations and interviews which were then inventoried, and identified for later processing and analysis based on qualitative methods, as material in finding answers to problems.

The qualitative approach used aims to describe the concept of the Toba Batak community placing Tortor in their various activities. To obtain accurate data and information in this study, field research was conducted through interviews with resource persons who can provide information. This descriptive method is used in analyzing the structure of the Toba Batak tortor in the Toba Batak community. Research sites were carried out in a number of Batak Toba areas such as Humbang Hasundutasn, Samosir, Parapat, Medan, Medan City and Unimed Dance Education Study Program.

\section{Results and Discussion}

The discussion on tortor revitalization research is presented based on the results of preliminary studies and development results. The presentations are carried out in a structured manner: (1) Study of the existence of tortors in various traditional ceremonies, analysis of the need for teaching materials in the form of a tortor documentary film; (2) The results of the development will be in the form of preparation of teaching materials by the documentary tortor documentary media.

a. Tortor

For Batak people Tortor (dance) is not just a mere movement, but a tortor, is part of a traditional rite symbolically driven. Tortor is based on the philosophy of life of the Batak 
people. Literally, tortor means human body movements that are carried out regularly, become a habit and are recognized and supported. Tortor movements have patterns, are arranged according to customary rules, and have beauty and religious meanings.

At first tortor was related to animistic beliefs to bring magical power, which served to worship the gods, which came to be known as dance parts of art from the Toba Batak culture, and eventually became a tradition to the community because it was carried out in various activities. Tortor is still used in traditional parties, and has its own role for each of its support groups. Therefore tortor becomes a media to maintain and maintain the continuity of the social system. This function can be seen in traditional ceremonies, social interactions in the community, and social interactions that occur during the manortor (dancing).

\section{b. Tortor in the Life of the Toba Batak People}

In the Batak Toba traditional ceremony, there is an activity called "Margondang" in which it contains elements of dance and music. In the Batak proverb it also says "he was a gondang in siadong tortor" (where there is a gondang that tortor is heard). The close relationship between the gondang and tortor becomes a reference in the connection of each element involved in the ceremony, so that they are always there.

\section{c. Tortor in Indigenous Upacar}

Tortor for the Batak people is not just an artistic activity, but the inclusion of tortor is an obligation in the life of customs and traditions in the dadap na tolu system (kinship system). In its presentation, tortor is divided into two types, namely 1) Hatopan tortor and 2) Hapunjungan Tortor. Hatopan tortor is a form of general dance (no specialization) or custom. Participants in the event may dance (manortor), by doing simultaneous movements, such as totor hatopan ni suhut (general dance suhut) or tortor hatopan ni boru (general dance of the boru party). Sebalinya, Hapunjungan Tortor is a special dance, where not all participants in traditional events may be menortor. Due to the presentation for a particular purpose according to the ceremony or events Margondang.

Horja or work on traditional activities, including gondang and tortor. They do it in a position of position in Dalihan na tolu, which is shown in posture, hand movements and position with whom the manortor. The attitude of the dancer's body appears when two different elements meet (facing each other), for example hula-hula with borunya, or two people who have the same traditional position meet, for example suhut with dongan body. Even this posture supports the movement of the hands and the height of the hands in front of the dancers. The pattern of hand movements is the dominant movement and is the easiest to show one's position in the dancing together in horja.

\section{d. Tortor in Entertainment Shows}

At the entertainment program, tortor is also one of the materials included. Wherever the Batak people reside, they will include a tortor and participate in the manortor as an identity that has been carried out for generations. So there is a saying that says:

"And tartangishon, tumagonma tinortor hon" means that if there is a problem that we are unable to cry about, we better just dance (manortor).

So the Batak people entertain themselves by doing tortor, so that if the Batak people hear the gondang sound, consciously or not, they will irregularly manortor. In entertainment activities, even these tortors are often served or displayed to entertain tourists or for other entertainment activities. Aside from being a social entertainment, tortor presentation is conducted in competitions to celebrate anniversary or anniversary activities in several districts 
(Toba Samosir Regency, North Tapanuli Regency, Humbang Hasundutan Regency, and Samosir Regency), which have become the government agenda. The presentation of tortor is also an effort to involve the government in preserving Toba Batak culture through tortor presentation.

\section{e. Stage of Development of Teaching Materials}

The development of tortor teaching materials is done based on needs analysis by conducting interviews with samples to find out knowledge about tortors, resource persons (traditional figures, artists) experts in Batak and tortor culture. Then collect reference sources for the development of Toba Batak cultural teaching materials. Furthermore, conducting field research by compiling concept maps of teaching materials such as (a) grouping of tortors in sharing Batak Toba traditional activities, (b) linking field data and references in teaching material materials, (c) interpreting teaching material resources, (d) making synopsis of materials teaching, and (e) making a Toba Batak tortor board story.

The preparation of teaching materials is packaged in the form of (1) material introduction and understanding of the material, (b) film design including elements of the design, story board, and, (c) preparation based on learning objectives. The implementation is carried out based on the analysis of learning objectives, and the preparation of teaching materials. Followed at the trial stage the draft teaching material includes (a) identifying and classifying tortors in traditional activities through film and narrative texts and discussions; (b) mastery of teaching materials from the documentary film tortor and narration; (c) determine methods and media; (d) preparation of draft development of works based on teaching materials.

At the learning stage of the Toba Batak tortor, assessment is based on theoretical and practical understanding through creativity in developing traditional culture. Practical understanding is demonstrated through the ability to demonstrate / demonstrate the work of development. Understanding the theory is seen from the mastery of the task of recognizing Batak culture, mini research as a scientific competency that must be owned.

\section{Conclusion}

Presentation of Tortor which is currently quite rapidly developing, both in the form of traditional and in the form of reconstruction and revitalization of Toba Batak artists, was developed through art galleries and arts education institutions such as Pedan State University which has three study programs, namely Music Education, Education Dance and Performing Arts. Descriptions of tortor performances by art galleries both in the Batak tribal area and outside have been disseminated through Youtube media in various development models. The writer's hope for artists and creators of Toba Batak art in carrying out reconstruction and revitalization should not change.

\section{References}

[1] Judistira, K. Garna. Budaya Sunda : Melintasi Waktu Menantang Masa Depan. Bandung : Lemlit Unpad. (2008). 
[2] Ediwar "Rekonstruksi dan Revitalisasi Kesenian Rapa'i Aceh Pasca Tsunami”, Jurnal Recital vol 7 no 1 April

[3] Marsudi. "Pengembangan Media Digital Kriya Topeng Malang Untuk Pembelajaran Seni Budaya Sekolah Menengah Pertama”. Jurnal URNA, Jurnal SenI Rupa Vol 1, no 1. (2012).

[4] Awaludin Muin. "Keterampilan Berbasis Multimedia Interaktif Pada Pembelajaran Seni Budaya Di Sekolah Dasar". Jurnal Penelitian Pendidikan INSANI, Volume 20, Nomor 2, hlm. 133-135. (2017)

[5] Sugiyono. Metode Penelitian Tindakan Komprehensif. Bandung: Alfabeta. (2015). 